\title{
Public Law Perspectives on a Private Law Problem: Auto Compensation Plans
}

\author{
By Walter J. Blum and Harry Kalven, JR. \\ Professors of Law, The University of Chicago
}

The material which follows constitutes most of the opening section of the book of the same name, published by Little, Brown and Company, Boston, 1965. It appears here with the permission of the authors and of the publisher. The book, in turn, grew out of the Harry Shulman Lectures, delivered, in the authors' words, "jointly, but not quite simultaneously," at the Yale Law School in 1964.

In a general way we intend to discuss automobile accident compensation plans, but the center of our interest is somewhat different from that of others who have written on the subject. We are not responding directly to the practical problem of coping with carnage on the highways; nor are we concerned with the merits of any particular compensation plan. Instead our interest lies in exploring the underlying rationale of tort liability and compensation schemes, and we look upon auto accidents as providing both an active and a finite area for testing liability and compensation theories. Our concern therefore is with policy.

Speaking loosely, the main question is usually taken to involve a single choice between the common law system in which not all victims recover, and where inevitably there is delay in paying claims, and an auto compensation plan under which every victim would get something, including prompt payment of medical and emergency expenses. This is too stark a contrast because of possible variations both on the common law side and among auto compensation plans. Thus if we add to the common law both compulsory liability insurance and comparative negligence-neither of which can now be considered a radical change-we end up with a negligence system under which the vast majority of victims recover something, albeit not promptly. And similarly if we postulate a compensation plan which embodies a low ceiling on damages, we would have a scheme under which victims as a class bear a large part of the losses. Moreover, most of the plans which have been offered resemble the common law to the extent that all losses are thought of as being borne only by motorists and victims of accidents. If we were to conceive of the special combination of tort law and social insurance of the English variety as constituting a plan, it differs both from the common law and from other plans in that the public at large, through tax funds, bears part of the losses. But enough has been said to indicate why our subject cannot quickly be reduced to a simple policy choice.

The idea of a plan for auto accidents has been con- 
Public Law-

(Continued from page 6 )

spicuous for almost half a century, with the obvious analogy to workmen's compensation having suggested itself early. The topic today is as lively as it ever has been. Several factors may account for its re-emergence. The contemporary mood is again congenial to sociological research in law. It has seemed attractive to many to redo the Columbia study because the auto accident problem is a natural subject for large scale empirical research on which newly developed tools can be brought into play. In addition there is the enormous increase in insurance coverage for auto accidents. The ubiquity of insurance has sharpened the perception of the inefficiencies, costs and inequities of the present system for determining liability, measuring damages, and adjusting claims in or out of court. Another factor is the increased sensitivity to welfare. Concern has centered on the inability of the system to provide victims with prompt payment of their medical and emergency expenses. Finally, there has been the practical stimulus of urban court congestion which frequently has been blamed on auto accident cases crowding the dockets. More than one seasoned trial judge has argued that an auto compensation plan under an administrative agency would be the best solution to court delay.

Despite the renewed interest, current discussions of auto plans are largely unsatisfying. They lack any sustained confrontation of issues. The bar, although it might be expected to play the role of the experienced conservative and thus to supply a sharp challenge to the reform, has been bluntly hostile when not apathetic. At most an occasional spokesman has sallied forth in the journals to stigmatize the plans as socialistic departures from the American way of life. And even if the response had been different, many would view with skepticism any defense of the current system by the lawyers because of the bar's great financial stake in its preservation. At the other extreme, proponents of auto plans, largely from academic life, have concentrated on social engineering to produce results they have already accepted as desirable. They appear so convinced that auto plans are the coming thing that they see no point in debating the merits of inevitable social change. Thus, although an appreciable amount has been written about plans, very little has centered on the kinds of policy issues which are to be our primary concern.

Indeed the special flavor of our policy concerns is the source of our collaboration in this essay. A bedrock question for us is the old-fashioned inquiry, who is to pay the bill? Payments to victims under compensation plans are compulsory payments under the coercion of the state, and obviously someone in the society must bear the cost. Allocating the cost of plans raises a fundamental question of fairness. It strikes us as odd that this issue should figure so little in current discussions. The incidence of liability has been the classic question for the common law torts man; and yet the allocation of costs is simply another name for the allocation of liability. The oddity is that the common law torts man should lose all interest in the question when a shift is made from the common law to a compensation plan. We suspect we know the reason. Torts has been regarded as a private law topic concerned with resolving the disputes between particular individuals. But when one turns to insurance funds and compensation plans, the matter becomes alchemized into public laws dealing with large groups in the society; and the result is that the private law expert has little interest in following through the questions which now seem to lie beyond the realm of his own special competence. Nor in their present stage of development have auto compensation plans engaged the attention of public law men, who have continued to center their interest on taxation and social security and other welfare systems. The topic has therefore fallen into a kind of no-man's land.

The design for our collaboration should now be clear. We hope to combine the perspectives of the teacher of private law and the teacher of public law on a topic that seems to need the attention and skills of both. 